\title{
Systematic review on efficacy of mifepristone and misoprostol combination on early trimester medical termination of pregnancy
}

\author{
Punyatoya Bej ${ }^{1 *}$, Sambhunath Das ${ }^{2}$ \\ ${ }^{\mathbf{1}}$ Associate Professor, ${ }^{2}$ Professor, Dept. of Community Medicine, ${ }^{\mathbf{1}}$ Dr. Baba Saheb Ambedkar Medical College, Rohini, Delhi, ${ }^{\mathbf{2}}$ All India \\ Institute of Medical Sciences, New Delhi, India
}

*Corresponding Author: Punyatoya Bej

Email: punyatoyabej@gmail.com

\begin{abstract}
Introduction: Mifepristone, also known as RU 486 is used to cause medical abortion during the early part of pregnancy. It is used up to 10 weeks of pregnancy. Mifepristone blocks the secretion of progesterone. Misoprostol is an analogue of prostaglandin that increases uterine contraction and cervical dilation. The combination of both is used in studies with variable efficacy for medical abortion.

Objective: To find out the efficacy of mifepristone and misoprostol combination by systematic review of studies from different parts of the world.

Materials and Methods: Literature search in internet was conducted with the topic of efficacy of mifepristone and misoprostol combination on early trimester medical termination of pregnancy. Sixteen articles were finalized after applying the review criteria. Four large trials on the efficacy of mifepristone and misoprostol conducted in USA and Australia and 12 studies from different parts of the world were included. Most of the studies are randomised control trials and descriptive type.

Results: It was found that the efficacy of mifepristone and misoprostol varied from $70.93 \%$ to $100 \%$ with a mean of $92.19 \%$. The time interval between intake of mifepristone and misoprostol, and complete abortion varied from $10 \mathrm{hrs}$ to $24 \mathrm{hrs}$.
\end{abstract}

Conclusion: Systematic review detected the mean efficacy of mifepristone and misoprostol combination to be $92.19 \%$.

Keywords: Early trimester termination of pregnancy, Efficacy, Mifepristone, Misoprostol, Systematic review.

\section{Introduction}

Mifepristone, also known as RU 486 is used for medical abortion during the early part of a pregnancy. ${ }^{1}$ It is used up to 10 weeks of pregnancy. Mifepristone blocks the secretion of progesterone, which is needed for continuation of pregnancy. Mifepristone always used along with misoprostol. Mifepristone stimulate contraction of the uterus resulting in expulsion of product of conception. Mifepristone was developed in 1980 and came into use in France in 1987. It became available in the United States in 2000. It is on the WHO list of essential medicines, the most effective and safe medicine needed in a health system. Common side effects include abdominal pain, feeling tired and vaginal bleeding.

Misoprostol is a commonly used prostaglandin to induce labour. Misoprostol sold under the brand name 'Cytotec'. 2 Misoprostol plays critical role in cervical ripening by increasing inflammatory mediators in the cervix and inducing cervical remodelling. Misoprostol exert different effects on these processes and on myometrial contractility. It is a medication used to start labour, cause an abortion, prevent and treat stomach ulcers, and treat postpartum bleeding due to poor contraction of the uterus. ${ }^{3}$ For abortions it is often used with mifepristone or methotrexate. ${ }^{4}$ An article on overview of medical abortion for clinical practice by Bryant $A G$ et al found that the effectiveness for termination of pregnancy is between $66 \%$ and $90 \% .^{5}$ It is taken either in the cheek, under the tongue, or placed in the vagina.

Common side effects of misoprostol include diarrhoea and abdominal pain. Misoprostol was developed in 1973. It is on the World Health Organization's list of essential medicines, the most effective and safe medicines needed in a health system. It is available as a generic medication.

Hence in the present systematic review, studies are included to find out the duration between the intake of mifepristone in combination with misoprostol and successful completion of abortion. The efficacy of mifepristone was calculated based on these studies.

The Objective is to determine the efficacy of mifepristone and misoprostol combination by systematic reviewing studies from different parts of the world.

\section{Materials and Methods}

The studies were searched in PubMed by putting the key word mifepristone, misoprostol, combination, efficacy and early trimester medical termination of pregnancy for time period of $1^{\text {st }}$ January 2001 to $31^{\text {st }}$ December 2018. Total 84 articles were collected by the search. Among those, 16 studies were finalized after applying the inclusion and exclusion criteria. The combine mean weight of all the studies was calculated by as the summation of multiplies of efficacy of the drugs with sample size of each studies divided by summation of each sample sizes.

Criteria for considering studies for review.

\section{Inclusion criteria}

The studies in which both mifepristone and misoprostol are used for medical abortion in early pregnancy were included. The efficacy of mifepristone and misoprostol are mentioned in the studies. Simultaneously the time interval between start of therapy and complete abortion were also mentioned in the studies. 


\section{Exclusion criteria}

The studies in which only mifepristone or only misoprostol is used excluded in the review process. The studies not mentioning the efficacy were not included.

\section{Search strategy for identification of relevant studies}

1. Search from the bibliographic databases

2. Selecting studies for inclusion

3. Quality appraisal of included studies

The effect size or the efficacy of mifepristone was calculated by using Gene Glass's approach. ${ }^{6}$ There are several ways to calculate the effect size. The three most popular approaches are Gene Glass's approach, Hunterschmidt's approach, and Cohen's d. ${ }^{7}$ The basic formula of Gene Glass's approach is difference between mean of control group and mean of treatment group divided by standard deviation of the control group.

In this study 16 studies collected on efficacy of mifepristone and misoprostol. The interval between intake of mifepristone and misoprostol and complete abortion was analysed. The efficacy of mifepristone and misoprostol on each study was combined and then the single combined effect size or combined efficacy level of mifepristone and misoprostol was derived.

In all these studies mifepristone and misoprostol were given to pregnant women in their first trimester of pregnancy for medical abortion. Efficacy of mifepristone was evaluated by assessing the complete abortion. Complete abortion was assessed by completely aborted or not completely aborted. Standard deviation or $95 \%$ confident interval were not available in many these studies. Hence in the present study, the efficacy of mifepristone was calculated by taking the average mean of efficacies of all the studies combined.

\section{Result}

Mean efficacy of mifepristone and misoprostol from 16 studies was calculated by addition of efficacy of individual studies divided by 16 . Statistical analysis was performed with SPSS 20 version. The mean efficacy of mifepristone and misoprostol was calculated to be $92.19 \%$ (Table 1).

Table 1: Details of all the 16 studies are described

\begin{tabular}{|c|c|c|c|c|c|}
\hline Authors & $\begin{array}{c}\text { Year of } \\
\text { study }\end{array}$ & $\begin{array}{l}\text { Drug used and } \\
\text { gestational week }\end{array}$ & Sample size & $\begin{array}{c}\text { Efficacy } \\
(\%)\end{array}$ & $\begin{array}{c}\text { Type of study and place } \\
\text { of study }\end{array}$ \\
\hline $\begin{array}{l}\text { Joensuu-Manninen } \\
\mathrm{H}^{8}\end{array}$ & 2003 to 2005 & $\begin{array}{c}\text { Mifepristone \& } \\
\text { misoprostol, 12-24 } \\
\text { weeks }\end{array}$ & 90 & $94 \%$ & $\begin{array}{c}\text { Retrospective, } \\
\text { observational , Finland }\end{array}$ \\
\hline Creinin $\mathrm{MD}^{9}$ & 2001 & $\begin{array}{c}\text { Mifepristone and } \\
\text { misoprostol, } 7 \text { weeks }\end{array}$ & 86 & $70.93 \%$ & $\begin{array}{l}\text { Prospective, randomised } \\
\text { trial, Pennsylvania, USA }\end{array}$ \\
\hline Gatter $\mathbf{M}^{10}$ & 2015 & $\begin{array}{c}\text { Mifepristone \& } \\
\text { misoprostol, } 9 \text { weeks }\end{array}$ & 13,373 & $97.7 \%$ & Descriptive, USA \\
\hline P. Yamini ${ }^{11}$ & 2016 & $\begin{array}{l}\text { Mifepristone and } \\
\text { misoprostol, } 5 \text { - } 9 \\
\text { weeks }\end{array}$ & 50 & $94 \%$ & Descriptive, India \\
\hline Szu-Yuan Chou ${ }^{12}$ & 2004 & $\begin{array}{c}\text { Mifepristone and } \\
\text { misoprostol, } 7 \text { weeks } \\
\text { of gestation }\end{array}$ & 149 & $72.48 \%$ & Descriptive, Tapei Taiwan \\
\hline Kumari Meenakshi ${ }^{13}$ & 2017 & $\begin{array}{l}\text { Mifepristone and } \\
\text { misoprostol, } 13-20 \\
\text { weeks of gestation }\end{array}$ & 30 & $100 \%$ & Descriptive, India \\
\hline Fyfe $\mathrm{R}^{14}$ & 2009 to 2014 & $\begin{array}{l}\text { Mifepristone, } 20 \text { to } 41 \\
\text { weeks of gestation }\end{array}$ & 63 & $100 \%$ & $\begin{array}{c}\text { Retrospective cohort, } \\
\text { Australia } \\
\end{array}$ \\
\hline Mitchell $\mathrm{D}^{15}$ & 2011 & $\begin{array}{c}\text { Mifepristone and } \\
\text { misoprostol, } 7 \text { weeks } \\
\text { of gestation }\end{array}$ & 2121 & $\begin{array}{l}95 \% \text { to } \\
96 \%\end{array}$ & $\begin{array}{c}\text { Descriptive, Data from US } \\
\text { mifepristone, misoprostol } \\
\text { trial, New York America }\end{array}$ \\
\hline Song LP ${ }^{16}$ & 2018 & $\begin{array}{l}\text { Mifepristone and } \\
\text { misoprostol, } 7 \text { weeks } \\
\text { of gestation }\end{array}$ & 533 & $94.4 \%$ & $\begin{array}{c}\text { Randomised Control Trial, } \\
\text { USA and China }\end{array}$ \\
\hline Schreiber $\mathrm{CA}^{17}$ & 2018 & $\begin{array}{l}\text { Mifepristone and } \\
\text { misoprostol }\end{array}$ & 300 & $83.8 \%$ & $\begin{array}{c}\text { Randomised Control Trial, } \\
\text { USA }\end{array}$ \\
\hline Sinha $\mathrm{P}^{18}$ & 2018 & $\begin{array}{l}\text { Mifepristone and } \\
\text { misoprostol, } 9 \text { weeks } \\
\text { of gestation }\end{array}$ & 92 & $86.7 \%$ & $\begin{array}{c}\text { Randomised Control Trial, } \\
\text { India }\end{array}$ \\
\hline Goldstone $\mathrm{P}^{19}$ & 2013 to 2015 & $\begin{array}{l}\text { Mifepristone and } \\
\text { misoprostol, } 9 \text { weeks } \\
\text { of gestation }\end{array}$ & 15,008 & $95.16 \%$ & Descriptive, Australia \\
\hline
\end{tabular}




\begin{tabular}{|l|c|c|c|c|c|}
\hline Verma ML & 2017 & $\begin{array}{c}\text { Mifepristone and } \\
\text { misoprostol, 9 weeks }\end{array}$ & 200 & $96 \%$ & $\begin{array}{c}\text { Randomised Control } \\
\text { Trial,(Parallel design) } \\
\text { India }\end{array}$ \\
\hline Louie $\mathrm{KS}^{21}$ & 2016 & $\begin{array}{c}\text { Mifepristone and } \\
\text { misoprostol, 13-22 } \\
\text { weeks }\end{array}$ & 120 & $99.2 \%$ & \begin{tabular}{c} 
Descriptive, Armenia \\
\hline Chen MJ
\end{tabular} \\
\hline Li CL & 2005 to 2015 & $\begin{array}{c}\text { Mifepristone and } \\
\text { misoprostol, 10 weeks }\end{array}$ & 33,846 & $96.7 \%$ & Systematic Review, USA \\
\hline & 2012 to 2014 & $\begin{array}{c}\text { Mifepristone and } \\
\text { misoprostol, 3 weeks }\end{array}$ & 650 & $98.6 \%$ & Descriptive, China \\
\hline
\end{tabular}

\section{Discussion}

The systematic review of the available studies between the years 2001-2018 detected mean efficacy of mifepristone and misoprostol combination use in early trimester medical termination of pregnancy is $92.19 \%$.

Systematic reviews are studies that are performed using a systematic approach to minimize selection bias and random error in compiling the published studies compare to common narrative reviews. ${ }^{24}$ It gives the final efficacy or outcome of a particular drug or intervention for therapeutic use in clinical practice by systematically analysing the results of all studies. Systematic reviews may or may not include meta-analysis. Meta-analysis is a statistical analysis of the results from independent studies, which generally aims to produce a single, typical estimate of a treatment effect. Other way, meta-analysis can be explained as a statistical combination of results from several studies to produce a single estimate of the effect of an intervention. Meta-analysis is a quantitative, formal, epidemiological study design used to systematically assess the results of previous research to derive conclusions. Meta-analysis is performed commonly for randomised control trial.

The dose of mifepristone was $600 \mathrm{mg}$ and misoprostol $400 \mathrm{mcg}-800 \mathrm{mcg}$ in most of the studies. The routes of use of misoprostol were oral, sublingual, buccal and vaginal. Vaginal route of administration had fewer side effects with higher efficacy. ${ }^{9}$ The time interval between ingestion of mifepristone and misoprostol was varies from $24 \mathrm{hrs}-48 \mathrm{hrs}$.

The successful termination of pregnancy was maximum within $24 \mathrm{hrs}$ of starting the drugs. Induction to abortion duration was shorter in multiparous and uniparous, compared to longer duration in nulliparous. ${ }^{8}$ The success rate and efficacy higher in smaller gestational age up to 63days. ${ }^{10}$ Even than Joensuu-Manninen $\mathrm{H}$ et al used the drugs in $2^{\text {nd }}$ trimester (12-24week gestation) with a success rate of $94 \% .{ }^{8}$ Medical termination with mifepristone and misoprostol is safer than surgical method in early trimester. The side effects are less with minimal incidence of nausea, vomiting and diarrhoea.

The strength of the systemic review is that the studies were from all over the world and some studies had large sample size up to $15008 .{ }^{19}$ Limitation of the review is all the 16 studies analysed were not randomized trials, hence some degree of bias may not be excluded.

\section{Conclusion}

In all the studies the medical abortion was conducted among pregnant females. It was found that the efficacy of mifepristone and misoprostol combination varies from $70.93 \%$ to $100 \%$. By combining 16 studies the mean efficacy of mifepristone and misoprostol was found to be $92.19 \%$. The time interval between intake of mifepristone and misoprostol and complete abortion varies from $10 \mathrm{hrs}$ to $24 \mathrm{hrs}$.

\section{Acknowledgement}

Nil.

\section{Source of funding}

None.

\section{Conflict of interest}

None.

\section{References}

1. Mifeprex (Mifepristone (RU486)): https://www.rxlist.com/mifeprex-ru486drug.htm\#description

2. Pharmacia. Cytotec (misoprostol) tablets prescribing information. Chicago, IL; 2003.

3. The American Society of Health-System Pharmacists. Archived from the original on 2015-02-21. Retrieved Feb 20, 2015.

4. Kulier R, Kapp N, Gülmezoglu AM, Hofmeyr GJ, Cheng L, Campana A. "Medical methods for first trimester abortion". The Cochrane Database of Systematic Reviews (11): (9 November 2011). CD002855. doi:10.1002/14651858.CD002855.pub4. PMID 22071804.

5. Bryant AG, Regan E, Stuart G. An overview of medical abortion for clinical practice. Obstet Gynecol Surv 2014;69(1):39-45.

6. Glass, G. V., McGraw, B., and Smith, M. L. (1981). Metaanalysis in social research. Beverly Hills, CA: Sage Publications.

7. Yu, C. (2001). Meta-analysis and effect size. Retrieved July 20, 2003 from:

http://seamonkey.ed.asu.edu/ alex/teaching/WBI/es.html

8. Joensuu-Manninen H, Kuvaja P, Talvensaari-Mattila A. Clinical efficacy of mifepristone and misoprostol in second trimester pregnancy termination. Acta Obstet Gynecol Scand 2010;89(12):1552-6.

9. Creinin MD, Schwartz JL, Pymar HC, Fink W. Efficacy of mifepristone followed on the same day by misoprostol for early termination of pregnancy: report of a randomised trial. BJOG 2001;108(5):469-73. 
10. Gatter M, Cleland K, Nucatola DL. Efficacy and safety of medical abortion using mifepristone and buccal misoprostol through 63 days. Contracept 2015;91(4):269-73. doi: 10.1016/j.contraception.2015.01.005. Epub 2015 Jan 13.

11. P. Yamini Shobha Vani, A. Niranjani Devi. Efficacy of Mifepristone and Misoprostol combination in termination of early pregnancy. Int Arch Integr Med 2016;3(12):48-54.

12. Szu-Yuan Chou, Pui-Ki Chow, Chin - Fen Wu, So-Jung Liang, Chun- Sen Hsu. Efficacy of

Mifepristone/Misoprostol Combination for Medical Abortion Determined by Detection of Retained Products in a Community Hospital in Taipei, Taiwan. Taiwanese J Obstet Gynecol 2004;43(2):77-9.

13. Kumari Meenakshi, Murari Krishna, Kumari Mamta. Safety and efficacy of Mifepristone plus Misoprostol in Second Trimester Termination of Pregnancy in Previous CS. J Med Sci Clin Res 2017;5(1):15395-7.

14. Fyfe R, Murray H. Comparison of induction of labour regimes for termination of pregnancy, with and without mifepristone, from 20 to 41 weeks gestation. Aust N Z J Obstet Gynaecol 2017;57(6):604-608

15. Creinin MD, Spitz IM. Use of various ultrasonographic criteria to evaluate the efficacy of mifepristone and misoprostol for medical abortion. Am J Obstet Gynecol 1999;181(6):1419-24.

16. Song LP, Tang SY, Li CL, Zhou LJ, Mo XT. Early medical abortion with self-administered low-dose mifepristone in combination with misoprostol. J Obstet Gynaecol Res 2018; 44(9): 1705-1711

17. Schreiber CA, Creinin MD, Atrio J, Sonalkar S, Ratcliffe SJ, Barnhart KT. Mifepristone Pretreatment for the Medical Management of Early Pregnancy Loss. $N$ Engl J Med 2018;378(23):2161-70. doi: 10.1056/NEJMoa1715726.

18. Sinha P, Suneja A, Guleria K, Aggarwal R, Vaid NB. Comparison of Mifepristone Followed by Misoprostol with Misoprostol Alone for Treatment of Early Pregnancy Failure: A Randomized Double-Blind Placebo-Controlled
Trial. J Obstet Gynaecol India 2018;68(1):39-44. doi: 10.1007/s13224-017-0992-5. Epub 2017 Apr 22.

19. Goldstone P, Walker C, Hawtin K. Efficacy and safety of mifepristone-buccal misoprostol for early medical abortion in an Australian clinical setting. Aust N Z J Obstet Gynaecol 2017;57(3):366-71. doi: 10.1111/ajo.12608. Epub 2017 Mar 17.

20. Verma ML, Singh U, Singh N, Sankhwar PL, Qureshi S. Efficacy of concurrent administration of mifepristone and misoprostol for termination of pregnancy. Hum Fertil (Camb) 2017;20(1):43-47. doi:

10.1080/14647273.2016.1243817. Epub 2016 Nov 2.

21. Louie KS, Chong E, Tsereteli T, Avagyan G, Abrahamyan $\mathrm{R}$, Winikoff B. Second trimester medical abortion with mifepristone followed by unlimited dosing of buccal misoprostol in Armenia. Eur J Contracept Reprod Health Care 2017;22(1):76-80. doi: 10.1080/13625187.2016.1258461. Epub 2016 Nov 21.

22. Chen MJ, Creinin MD. Mifepristone with buccal misoprostol for medical abortion: A systematic review. Obstet Gynecol 2015;126(1):12-21.

23. Li CL, Chen DJ, Deng YF, Song LP, Mo XT, Liu KJ. Feasibility and effectiveness of unintended pregnancy prevention with low-dose mifepristone combined with misoprostol before expected menstruation. Hum Reprod 2015;30(12):2794-801. doi: 10.1093/humrep/dev239. Epub 2015 Sep 23.

24. Uman LS. Systematic reviews and meta-analyses. J Can Acad Child Adolesc Psychiatry 2011;20(1):57-9.

How to cite this article: Punyatoya Bej, Sambhunath Das. Systematic review on efficacy of mifepristone and misoprostol combination on early trimester medical termination of pregnancy. J Community Health Manag 2019;6(3):68-71. 